\title{
Proverbs in marriage: Counselling role and implications
}

A great marriage is not when the perfect couple comes together. It is when an imperfect couple learns to enjoy their differences (Meurer, 2000)

\section{Charles Owu-Ewie}

\author{
Associate Professor \\ University of Education, Winneba \\ College of Languages Education, Ajumako \\ Faculty of Ghanaian Languages Education, Ajumako \\ Email: owuewie1@gmail.com
}

Submitted: April 16, 2018 / Accepted: December 4, 2018 / Published: October 4, 2019

\begin{abstract}
The Akans of Ghana perceive marriage as an important ritual and an aspect of their sociocultural life. Because of the importance attached to marriage and due to the fact that it is a preserve for the matured in society, the language used for its contraction is sophisticated and infused with proverbs. In recent times, the role of proverbs as a marriage-counselling tool has been overlooked in contemporary counselling. This paper, from a Pragmatic and Relevance Theory (RT) perspective, looked at the counselling role Akan proverbs play in marriage contraction. This descriptive qualitative study purposively selected proverbs in three episodes in different contexts of marriage contraction to see how they were used as counselling tools. The analysis of the data indicated that proverbs play a major counselling role in marriage. The counselling roles concentrated on themes like patience, co-operation, respect, sex, self-denial, hard work, faithfulness, loyalty, humility, child bearing and caring, and love. The implication is that contemporary professional marriage counsellors and priests should employ proverbs in their counselling sessions because proverbs portray what the Akan cherish as their worldview and an embodiment of their soul. This will ensure a clear understanding of the complexities of marriage.
\end{abstract}

Keywords: Proverbs, counselling, Akan, marriage 


\section{Introduction}

A proverb is a communicating tool used to describe and express social, cultural, natural and other events or practices (Odebunmi, 2008). It is rare to communicate effectively in the African context without using proverbs, especially if the speaker is dealing with issues that border on the values, norms, institutions and on the whole gamut of the people's experience. Proverbs are indispensable in African communication. They are tied to the philosophy, experience and cognitive abilities of people (Agyekum, 2012). Among the Akans of Ghana, proverbs permeate in any communication process. Their use makes a conversation very highly regarded. One's ability to use proverbs appropriately in speech indicates one's communicative competence (Agyekum, 2012). This implies that the use of appropriate proverbs strengthen and support significant traditional value or belief. Among the Akans, any elaborate social activity, including marriage is characterized by the profuse use of proverbs.

Marriage is a beautiful but serious customary ritual, which the Akans of Ghana revere. The language used in marriage ceremonies, sometimes is shrouded in secrecy to indicate that it is for serious minded people. On such occasions, speakers usually embellish their language with proverbs to indicate their communicative competence and add beauty to the ceremony. Participants, especially the elderly shroud their language in proverbs to counsel the couple to make their utterance provoke them to think critically and then take lessons from it. As Wierzbicka (1988) succinctly indicates, culturally important objects and concepts have rich vocabulary or expressions to describe them. In traditional marriages, the Akan use proverbs to counsel couples. However, professional counsellors have not exploited this phenomenon fully in contemporary marriage counselling. Contemporary professional marriage counsellors use scripted, learned information and biblical verses, where necessary to counsel their clients to the neglect of using traditional proverbs, which are grounded on the values and shared beliefs held by the speech community (van Heerden, 2013). There is the need, therefore to bring to the fore the specific counseling roles of proverbs in marriage contraction among the Akans and how contemporary marriage counsellors can exploit them to the benefit of their young and inexperienced clients. 


\section{Literature Review}

This section of the paper deals with the definition, characteristics and importance of proverbs. It also examines some empirical studies on Akan proverbs in marriage.

\section{The concept and importance of proverbs}

The concept proverb, also known as paremy has numerous definitions posited by different authors depending on their focus. Since authors have defined proverbs differently, Barajas (2010: 49) indicates that "determining when an utterance may be understood as a proverb has been elusive because structural variation bounds among proverbial utterances". In the view of Villers (2016), many conflicting definitions exist, mainly because proverbs are at the crossroads of several disciplines: folklore, semantics, stylistics, sociolinguistics, and narrative studies. This has resulted in difficulty in providing easier definitions for a proverb bringing about the proliferation of names given to utterances that are proverbial in nature like apothegm, aphorism, adage, maxim, saying and wellerism. This notwithstanding, attempts have been made at defining the concept.

A proverb is a philosophical and moral exposition shrunk to a few words, and forms a mnemonic device in societies in which everything worth knowing and relevant to the day-to-day life has to be (Obiechina, 1975). In a slightly complicated way, a proverb is a popular set phrase having no author, known mostly in different languages, expressing in one sentence a principle, advice, a genuine or assumed truth in a general, concise form, its basic idea being of general validity, or at least its user considers it as such (Nagy, 1979: 645).

Yusuf (1998) also perceives a proverb as a short repeated witty statement of experience, which is used to further a social end. In the same vein, Akporoboro (2008) sees a proverb as a short popular saying usually in the form of a moral advice or truth expressed in a concise form. As a face-saving device, proverbs are cleverly constructed belief statements, which are used to help users to say unpleasant things in an ameliorated way (Alimi, 2012).

From a pragmatic perspective, proverbs are interesting pieces of popular wisdom and tradition belonging to any culture, which help people to foreground their values and shared beliefs (Ramirez, 2015). Besides these definitions, Agyekum (2012) provides another dimension to the definition of proverbs by indicating that it is a time tested, belief and witty saying, 
which usually symbolizes and expresses a truth or recognized observation about practical lines, based on traditional experiences. According to Agyekum, proverbs are transmitted from generation to generation. From the definitions above, a proverb can be encapsulated to mean a time tested, short, witty and cultural oriented statement with moral underpinning, which has been handed over from generation to generation in a particular culture with no particular author.

The various definitions above show that proverbs possess some unique characteristics. In the first place, they are short wise sayings, which are pithy and terse (Yankah, 1989). This means they communicate a lot of information in a few words. They are brief and to the point; a single statement that is infused in speech. Proverbs pertain to imagery and mnemonics, which implies that the choice and arrangement of words in proverbs are carefully considered. Additionally, proverbs are crystals of language and culture, loaded with accumulated wisdom and strong ethnic characteristics and distinct cultural implications (Aboh, 2013). Besides, proverbs are readily available in recurrent situations and are available as performed utterances, which meet the speaker's need for formulating an original utterance of her/his own (Shariati \& Tayebi, 2012). Proverbs are also seen as inventorized units, which signal group membership (Hain, 1951, cited in Norrick, 1985) and as quoted traditional material, which reinforces their apartness from their context (Abraham, 1968). Lastly, proverbs are perceived as indirect speech acts, which do not make the speaker explicit (Searle, 1975a; Agyekum, 2012). This makes proverbs invoke higher order thinking in their listeners (Norrick, 1985).

Proverbs play an important role in African societies in general and in Ghana in particular. The importance of proverbs, or proverbial sayings in the Akan society is captured in this proverb, which is well known to the Akan people of Ghana; "A wise person is spoken to in proverbs, not in prose." The point is that a wise person does not always need a lengthy discourse in order to be convinced of the right thing to do. This implies that a fitting proverb stimulates thinking, impacts understanding, and can motivate one to do what is right. In the words of Agyekum (2012: 9),

Proverbs are an indispensable aspect of Ghanaian life and are tied up to the philosophy, experience and the cognitive abilities of the people. They are one of the mechanisms for the education and socialization of children.

According to Alimi (2012), proverbs are highly regarded in African traditional societies because they are used to portray certain actions or 
events in a picturesque manner. They make events come live and vivid to the listener. In addition, proverbs are used as a means of transmitting the code of conduct, sense of humor and wisdom of people from one generation to another. For example, the Akans have a proverb which says "wo were fir wo kurom hen abentsia a, eyew eguabs ase" (if you forget the meaning of your village chief's horn message, you get lost during celebrations). In another perspective, proverbs are seen as the repository of native intelligence, code of moral laws and philosophy of both life and social justice (Alimi, 2012). Proverbs are used to foreground the values and shared beliefs of a speech community. In the view of Wunderlich (1972, cited in Norrick, 1985), proverbs allow the speakers to disguise their true feelings, to leave themselves an escape route to offer their hearers choices and to indicate real or imagined consensus. Finally, the use of proverbs in communication enables the speaker to avoid personal commitment and refutation (Taylor, 1962, cited in Basgoz, 1993; Arewa \& Dundes, 1964 and Barley, 1970).

\section{Studies on Akan proverbs}

The study of proverbs has attracted many scholars to delve into the various aspects of the concept. There have been pragmatic, socio-cultural, semantic, syntactic and socio-linguistic studies of proverbs. The study of proverbs has also been applied to other areas like literary works (Odebunmi, 2008; Rezaei, 2012; Alimi, 2012; Devi, 2015), administration (Simon, 1946), gender construction (Dogbevi, 2011), gender and power relations (Rasul, 2015; Agbemabiese, 2016; Aku-Sika, 2016), and conflict management and resolution (Aden, 2010; Ademowo \& Balogun, 2014).

In recent times, studies on proverbs have shifted from simple compilation of proverbs to applying them to other disciplines. Two authors who have done massive compilation of Akan proverbs are Christaller (1879) and Appiah, et. al. (2007). These two works provide a corpus of Akan proverbs, which other authors draw from to enhance their empirical studies. Yankah (2012), in his book, The proverb in the context of Akan rhetoric notes that just documenting African proverbs in general and Akan proverbs in particular is not enough. In his book, the author portrays the use of proverbs as dynamic communicative strategy in which form, meaning and logic are in constant interaction. He stipulates that proverbs are in the heart of real discourse interactions and that they have rhetorical importance based on indigenous aesthetics. 
In an empirical study on Akan proverbs, Quan-Baffour (2011) analyzed some Akan proverbs to examine their educational importance for the contemporary generation. Quan-Baffour noted that Akan proverbs are crucial in developing the social skills and emotional intelligence of the youth. He also noted the encouragement of hard work and detest for laziness, self-reliance, unity, support, love and co-operation, warning against discrimination and communal life as aspects of the importance of proverbs.

Agyemang, Asumeng, and Amponsah (2015) also explored the uses of Akan proverbs in contemporary human resource principles and corporate values. The authors identified that Akan proverbs portray themes like teamwork, training and development, retirement planning, organizational ethics and synergy and collaboration in contemporary human resource. Other themes identified were delegation of functions, risk-taking, collective responsibility and accountability, feedback seeking and business planning.

Agyekum (2012) looked at the concept of marriage and analyzed proverbs and aphorisms about marriage. His aim was to examine how the Akans conceptualize marriage and all its values. The author analyzed proverbs used for marriage generally, those for pre-marriage, during the marriage contraction, and post-marriage. He noted that such proverbs have both positive and negative implications for marriage. These studies and others by Adu Gyamfi (1999), Opoku (1997), Kquofi, Amate and Tabi-Agyei (2013) indicate how proverbs in Akan can be applied to other areas of study. The current study expands the frontiers of these studies by examining how Akan proverbs are applied to contemporary marriage counselling issues.

\section{Purpose and Research Questions}

This study sought to investigate the use of proverbs as a counselling tool in marriage contraction among the Akans of Ghana. The study also examined the major themes that were frequently expressed with proverbs in marriage contraction to counsel couples and the implications of the use of Akan proverbs as counselling tool in contemporary professional marriage counselling. The study answered the following research questions:

1. What specific counselling themes do the Akans of Ghana use proverbs for in marriage contraction?

2. What themes are frequently expressed with proverbs to counsel couples during marriage contraction among the Akans? 
3. What are the implications of the present study to the professional counsellor's use of Akan proverbs in their dayto-day marriage counselling of their clients?

\section{Methodology and Conceptual Framework}

This section of the paper presents the methodology and discusses the conceptual framework.

\section{Methodology}

The study employed a qualitative ethnographic research design. The researcher used complete observation to gather data at various ethnographic situations that related to marriage contraction. This means the researcher was not a participant observer. The researcher purposively selected proverbs in three episodes in different contexts of marriage contraction with ten optional speeches. The study was conducted in three different communities in the Shama District of the Western Region of Ghana. The selected proverbs were from the optional speeches of participants on the day the marriage ceremony was performed. The marriages were conducted using the local language (Fante) but in this research, the researcher has provided the English translation of each episode (see appendix). To ensure credibility and observance of ethical issues, the researcher sought permission from participants before proceedings were recorded. In all, forty-four (44) proverbs from ten optional speeches of three marriage contraction episodes were analyzed. In the marriage contractions under discussion, only males spoke during the optional speeches. The ages of those who gave the optional speeches were between forty-five and seventy. There were a few women present but none of them spoke during the optional speeches. The data analysis for the counselling role of proverbs in marriage contraction was done using content analysis approach where there was categorization and coding. First, all the proverbs in the various episodes were identified, categorized into themes and then coded under the various themes. The frequency of themes expressed with proverbs in each marriage contraction was done by first doing a simple tally of the proverbs against the themes, converting the frequency to percentages and later presenting it on a bar chart. 


\section{Conceptual Framework}

This paper is underpinned by the Pragmatic Approach (PA) to the use and interpretation of proverbs proposed by Sperber and Wilson in 1986 and revised in 1995. The pragmatic approach deals with how thoughts are communicated from one person to another. By the use of coding and encoding, speakers encode their thoughts; that is, the listener receives the message and interprets it to arrive at the intended meaning envisaged by the speaker. A sub-strand of the pragmatic approach used in this study is the Relevance Theory (RT), which posits that receiving communication is a process of sifting through the available input to find the communication, which is of most relevance. In the fields of pragmatics and semantics, RT holds the principle that the communication process involves not only encoding, transfer, and decoding of messages, but numerous other elements, including inference and context (Clark, 2013). The core of the theory is the communicative principle of relevance, which states that by the act of making an utterance the speaker is conveying that, what has been said is worth listening to. In RT, implicit messages (i.e. proverbs) are relevant enough to be worth bothering to possess. In such instances, the speaker will be economical as possible but makes the utterance stand out clearly. Relevance theory argues that the thing that causes an input to stand out from others is its relevance to the receiver. Wilson and Sperber (1986: 252) indicate as a rule that "other things being equal, the greater the positive cognitive effects achieved by processing an input, the greater the relevance of the input to the individual at that time". This theory was used as an underpinning for this study because in counselling during marriage contraction, the proverbs used stand out from all other structures and this makes the couple (listeners) think critically to process and get the meaning of the utterance, which are of importance to them. This makes it relevant to them as the theory posits. In the current study, the utterances (proverbs) in the optional speeches of participants were selected to see how relevant they were to the couple (listeners).

\section{Data Analysis and Discussion of Findings}

The data analysis and discussion were done based on the research questions posed earlier in the study.

Research Question 1: What specific counselling themes do the Akans of Ghana use proverbs for in marriage contraction? 
In this section, the analysis and discussions are done based on the optional speeches made by participants during the marriage contraction processes. In Akan marriage contraction, there is a section where willing participants give optional speeches to advise or counsel the couple. This is done when all the important marriage rituals have been performed and the ceremony is about to end. This is where participants exhibit their eloquence by using proverbs and other communicative devices to attract the attention of the couple and make them think critically about the marriage journey they are about to embark on. It is a counselling period. Speakers at this time use sophisticated language to talk about themes essential to successful marriage. The use of such communicative devices signifies that marriage is for the serious minded and the mature individual. The researcher first presented the speeches in Fante and later translated them to English. The proverbs in each optional speech are italicized and assigned a code number. For the flow of analysis, the marriage contraction episodes are placed at the appendix but references are made to them as the analysis proceeds. Themes that emerged from the proverbs used in the optional speeches in the study as means of counselling the couple in the marriage contractions are examined below:

\section{Co-operation}

Co-operation is key to any successful marriage because marriage involves two different people coming together. These two individuals sometimes have different philosophies, attitudes, values, perceptions, ethnic, cultural and social-economic backgrounds who have come together as one entity. They need to work co-operatively to ensure the success of their marriage. Co-operation makes a marriage great, especially when the couple are quite different. As Meurer (2000) indicates, a great marriage is not when the perfect couple comes together but it is when an imperfect couple learns to enjoy their differences.

In the study, participants emphasized more on co-operation than any other theme. The proverbs used in this category concentrated on the need for the couple to shoulder the burden of marriage together and that one person cannot withstand the tribulations in marriage hence the proverb 'dua kor gye ehum $a$, obu' (if one tree stands in the way of the storm, it breaks) (episode 1 , optional speech 1 , proverb 3 ). In this category of proverbs, it became clear that the couple should do things together and that when the two commence a project they should see it to a successful completion together. Hence the 
proverb wonam beenu sua efir a, wonam beenu sera (When two people set a trap/snare the two people check it (episode 1, speaker 2, proverb 6). Some proverbs in the category also indicated that the couple should take decisions and confer together. The proverbs Tsir kor mmpam (9) (One head does not take decision) and Tsir kor so nnks egyina (10) (One head does not confer) (episode 1, speaker 2). Some of the proverbs signified that cooperation and working together brings about victory in marriage, as in the proverb korye ma nkoyimdzi (14) (unity brings about victory) (episode 1, speaker 3). In addition to the above, some proverbs were used to depict the importance of co-operation in marriage. The couple were admonished that doing things together helps them to accomplish any task, no matter how daunting it might be, as in the proverb Nkura yec kor no, wodzii mborkutu (17) (When the mice united they ate a full pot of dough) (episode 2, speaker 1). Besides, some of the proverbs used for co-operation as a means of advising the couple hinged on security, strength in doing things together and helping each other. These were expressed in the following proverbs: Huw m'enyi do ma me ntsi na atwe nam beenu beenu (18) (antelopes walk in pairs because of the idea of removing the peck from one's eye) (episode 2, speaker 1), Nyansa nnyi baakofo tsir mu (19) (Wisdom does not reside in one person's head) (episode 2 speaker 1), Nyimpa kor nsa nnso Nyame enyim kata (20) (One person's hand cannot cover the face of God)(episode 2, speaker 2), nsa nyimfa guar benkum na benkum so guar nyimfa (27) (the right hand washes the left and the left also washes the right hand) (episode 2, speaker 4), se nyin annwen na ber wen a, woda mu (28). (If the man does not weave/build and the woman builds, they sleep in it) (episode 2, speaker 4) and Pardze kunkumfi ne bu ycbuna (44) (A huge broom is difficult to break)(episode 3, speaker 2)

\section{Patience}

One attribute crucial to a healthy, happy and successful marriage is patience. Anger and frustration is unavoidable in marriage and for one to tolerate or restrain one's self from reacting to such situations, patience is essential. Patience allows the couple to think before they speak and react to each other. Having patience with each other in marriage, helps to reduce fights and unnecessary arguments, results in calm discussions and encourages good communication in marriage. Next to cooperation was the theme of patience which was also considered crucial by the optional speakers. The proverbs used in this category admonished the couple to be cautious 
and not to act hastily in whatever they do, hence the proverb obra wots bo bo (7) (No haste in life) (episode 1, speaker 2). Additionally, the couple were advised that patience brings about victory in marriage. These were evident in the proverbs abotar ma nkonyimdzi (15) (Patience results in victory) (episode 1, speaker 4). Anger is seen as a destructive element in marriage. The couple were therefore advised to desist from anger because where there is love in marriage, anger has no place hence the proverb beebiara $d s w$ no, ebufuw nnyi ho (16) (Where there is love, there is no anger) (episode 1, speaker 4). Again, patience is seen as having the potential of doing great things in marriage beyond the imagination of the couple and that when the couple are patient, they discover hidden things that will normally damage or cause the marriage to break down. These were expressed in the proverbs abotar tutu nkwokwaa (33) (Patience moves mountains) (episode 3, speaker 1) and isie abotar gua ntsctsea a, ihu n'ayamudze (34) (If you take time to dissect the ant, you see its intestines) (episode 3, speaker 1).

\section{Respect for In-laws}

In the data analysis, respect for in-laws was also seen as an important theme in counselling the couple. In-laws are seen in most cases as problems (controlling, interfering, cause of inconvenience and clash of values and traditions) in marriage (Chapman, 2015). So participants in their optional speeches used proverbs to indicate how couples should guard against this phenomenon and learn to live with their in-laws peacefully to ensure successful marriage. The success and failure of a marriage greatly depends on in-laws as indicated by these proverbs awargu na awars gyina nsewnom do (25) (the success or failure of marriage depends on in-laws) (episode 2, speaker 3) and awar wowar no ekyir (26/42) (marriage thrives on people behind it/in-laws) (episode2, speaker 3 and episode 3, speaker 2).

\section{Hard work}

Hard work is also an important variable in successful marriage. Among the Akans, a marriage can be dissolved because the man is lazy. The Akans want a hardworking man, who can put food on the table, pay the family dues of the wife, provide shelter for the family, educate and cloth his children. The Akans believe that hard work does not kill but makes a family wealthy, hence the proverb edwumadzen nnku nyimpa (hard work does not kill (human being) (episode 3, speaker 1). This is collaborated by an article in the The Telegraph (March 31, 2018) and Howarth (Jan. 27, 2017) that the key to a happy and successful marriage is having a hardworking 
man. The data also revealed that women should work hard to support their husbands; hence the proverb se nyin annwen na ber wen a, woda mu (If the man does not weave (build) and the woman does, we sleep in it) (28) (episode 2, speaker 4). In the analysis, it was found that if the man or the woman does not go out and work, the family will go hungry and things like shelter and clothing will elude them, hence the advice from the proverb Anoma enntu a, obua da (5) (If a bird does not fly, it goes hungry (episode 1, speaker 1). In the same way, the optional speakers advised the couple to work hard since staying at one point or home will not bring any good result and progress to the family. Such a behavior stifles the growth of the family and makes them poor. This advice was concealed in the proverb etse fakor a, etse w'adze do (21). (If you stay at one point, you stifle your progress)(episode 2, speaker 2). A proverb in this category also stressed the need for the couple not to stay aloof and complain of being hungry. The proverb akwadwer no nua nye menya medzi (the brother of laziness is, if I get, I will eat) (episode 1, speaker 1). This in reality means a lazy man will always complain of hunger and wish he could get something to eat and feed his family. The optional speakers emphasized hard work in the episodes because it makes a marriage have strong roots, harnesses hidden resources, makes the family rich and wealthy and makes them achieve results.

\section{Respect for each other}

Respect is one of the most important determinants of a successful and healthy marriage. According to Dashnaw (2018), the notion of respect in marriage cuts across both scientific and spiritual conceptions of marital intimacy. In the view of Dashnaw, marital satisfaction and a sense of "weness" are contingent upon the respect that spouses show toward one another. The key factors in ensuring respect in marriage are mutuality, reciprocity, accommodation and acceptance. In most cases, there is the perception that women should respect their husbands and this was reinforced in the proverbs used to counsel the couple in the study. The woman was advised to respect and be humble to the husband with no proverb on mutual respect and humility directed to the man. The woman, according to the proverbs used, should look up to the man in terms of decision-making, if she even knows more than the man does. The proverbs akoksber nyim adzekyee naaso shwe akoksnyin ano (The hen knows daybreak but it always looks up to the cock to crow) (24) (episode 2, speaker 3) and sbaa a sd no kun, daa ose morohwe woara (A woman who loves the husband, will always say 
Owu-Ewie, C./Legon Journal of the Humanities Vol. 30.1 (2019)

l am looking up to you) (29) (episode 2, speaker 4) attest to this assertion. However, as Dashnaw (2018) indicates, respect must be reciprocal in marriage and not only from the woman. This phenomenon prevailed in the proverbs because the Akan society is more patrilineal.

\section{Sexual Denial}

Based on the data, sex denial was also seen by the participants as a crucial factor in the collapse of marriages. The data revealed that sex in marriage was regarded as one of the key variables to marriage sustenance and that its denial can result in marriage breakdown. Sex is very much the 'glue' in a marriage, which makes the couple get closer. It consolidates the bond, which keeps the couple together and that, its denial can make the man polygamous and the woman adulterous. The proverb atopa na sma awar so (sex makes marriage blossom) (proverb 39) in optional speech 2 of episode 3 testifies to this. In this same category, some of the proverbs advised the woman not to push the man away when its time for sex. When this happens, the man is likely to be "snatched" by another woman or will

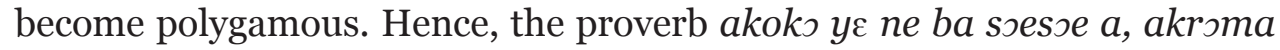
kyer no (if the fowl drives its chicken away, it is snatched by a hawk) (episode 2, speaker 4, proverb 32).

\section{Faithfulness/truthfulness}

Proverbs were used to counsel the couple on the need for them to be faithful and truthful to each other. Faithfulness in marriage makes the couple focus and this ensures peaceful coexistence. There is no love in marriage without faithfulness. In the proverbs used in counselling the couple, faithfulness was seen as the light, victory and the foundation rock for any successful marriage. The proverbs "nokwardzi ma nkonyim" (truthfulness/faithfulness results victory) (episode 2, speaker 4, proverb 30), nokwardzi (so) ye awar mu kandzea (truthfulness is the light in marriage) (episode 2, speaker 4, proverb 31) and nokwardzi nye awar no kutuwdobo (truthfulness is the bedrock of marriage) (episode 3, speaker 2, proverb 43) in the data, attest to the Akan thinking that faithfulness/ truthfulness is key to a successful marriage.

\section{Against Polygamy}

The Akans practise polygamy. This means that the traditional system permits a man to marry two or more women. In view of this, one would have expected that there will be proverbs in favor of polygamy but in this study, 
speakers used proverbs to advise the man against polygamy. The proverbs used indicated that when a man gets involved in polygamy, he sometimes goes hungry. He also becomes a liar as expressed in the following proverbs: awar dodow ma ksm dze banyin (having many wives makes a man go hungry) (episode 1, speaker 3, proverb 13) and awar dodow ma banyin n'ano ye nta (having many wives makes a man have double tongue) (episode 3, speaker 2, proverb 41). Traditionally, an Akan who has two or more wives was regarded as wealthy and as having good standing in the society. Such a man is highly respected in the society. However, in this study, the proverbs used went against this perception. The couple were advised against polygamy because as educated people, it was envisaged that they would have contemporary wedding in the church leading to signing a matrimonial certificate, which does not allow the man to marry another woman. Additionally, the current economic situation calls for a man to stay with a single wife so that he will be able to take good care of the family as expected.

\section{Excessive Friendship}

The proverbs used by the optional speakers in the study advised the couple, especially the woman against having excessive friends. The proverbs used indicated that having numerous friends could lead to losing your wife or husband. According to the Akans, in particular and other ethnic groups in general, some friends do more harm than good in marriage. Duenwald (2002) writes that some friends can be intrusive and invasive in marriage. Such friends can destroy a peaceful marriage. Truly, we need friends we can confide in but if that drives us away from our spouse, we are likely to destroy our marriage. It is this, which speakers (participants) spoke against by using the following proverb: anyenko dodow ntsi na kots ennya tsir (excessive friendship made the crab headless) (episode 1, speaker 1, proverb 2). The proverbs used also advised the couple to take good care of themselves to live long and to be able to protect their marriage for a longer time. The proverb nwaba kora noho na syc pe (the snail that takes good care of itself becomes the giant snail) (episode 3, speaker 1, proverb 36) proves such assertion.

\section{Provision of security}

Individuals have particular needs, which they are unable to meet on their own. They need support from others to help them meet such needs. A woman's greatest need in marriage is security. In marriage, men are to protect their family physically, especially the wife. Men are uniquely equipped to protect their families because of the greater physical strength they have. 
Men have the desire to be protectors than women. In the Akan society, men are supposed to provide security for their wives or sisters. The Akans believe that a man will beat a woman and bluff when the woman has no husband or brother to retaliate the assault. In counselling the couple, the man was advised to provide the needed security to the wife. This was evident in the proverb, basia onnyi kun na ycbor no yi akyia. (A woman who has no husband is the one who is beaten and followed with bluff) (episode 1, speaker 3, proverb 11). The implication is that the husband should physically protect his wife from other men physically assaulting her.

\section{Heeding to advice}

Heeding to advice in marriage is very crucial, especially if it is well intended. In Akan marriage contraction performances, participants advise the couple to listen to advice from each other and from well-meaning members of the family or community. Failure to listen to advice can lead to taking a wrong decision or landing into trouble. Most of the time, the woman is advised to listen to advice or counsel from the man. In the study, there was only one proverb meant for the woman on the need to heed to advice from the husband. The proverb warns the woman that failure to listen to advice from the man can result in unforeseen and indelible consequences. From the data, the proverb seanntse nye swam etsiks pow (Not heeding advice is why the horn-blower bird has a protruding head) (episode 1, speaker 2, proverb 8) is used to warn the woman of hardship in life, if she fails to heed to advice. Though this proverb was meant specifically for the woman, it also goes for the man, since each will have to heed to advice from the other.

\section{Against Violence}

Most ethnic groups, including the Akans of Ghana abhor violence in marriage. Violence in marriage includes partner abuse, wife assault, maltreatment, and many more. In Akan marriage contraction, the man is cautioned to desist from stretching the finger against the woman. This implies that the man should not physically assault the woman and that any such behaviour will result in a stiff and unparalleled retaliation from the woman's family (especially, brothers). The proverb edze kokrobetsir ko eyi $a$, wodze asotor gya wo kwan (If you attend a funeral with a raised thumb you are seen off with a slap) (episode 1, speaker 3, proverb 12) confirms this assertion. Physical violence against a wife in the Akan context, can result in marriage breakdown so couples are counselled with such proverb to desist from such an act. 


\section{Emulating good behaviour}

In the data analysis, it was identified that the couple were advised to be of good behaviour to ensure success of the marriage. In the optional speeches, the woman was asked to exhibit the good things and attributes that she had learned from her mother. It is believed that the woman displays good things like cooking, child caring and housekeeping she acquired from her mother in her marriage. The Akans hold the view that women go to their marriage with their mothers because what their mothers have taught them are what they exhibit in their everyday marriage life. Hence the proverb obaa ks awar a, snye ne na ks (1) (If a woman enters into marriage, she goes with her mother) (episode 1, speaker 1, proverb 1). Again, the couple were advised to emulate good things each of them does and the good things that other people have done to make their marriage successful. The proverbs used in this category also indicated that the couple should emulate people who do good things in the society. This proverb nyia syc adze pa na yetu n'ekyir gya (37) (The one who does good things is the one we emulate) used in counselling the couple attests to this.

\section{Child bearing}

The Akans believe that the bedrock of any marriage is children. Some marriages break down because the couple are unable to have children. Among the Akans, having children in marriage is cherished because when the man dies it is his children who will bury him. The absence of children in marriage means that when the man dies his family will bear all the expenses. Such people are buried in a different way from those who had children. The respect a man or a woman gets from marriage diminishes when there are no children in the marriage. In marriage contraction, the couple is advised to have children to ensure that the law of procreation and the survival of the extended family is upheld. The proverb awar mu enyimnyam nye mba (children brings reputation in marriage) (episode 3, speaker 1, proverb 35) used to counsel the couple means that having children in marriage elevates reputation in marriage.

Research Question 2: What themes are frequently expressed with proverbs as counseling tools in marriage contraction among the Akans?

From the data analysis, the following were identified: The counselling theme with the highest frequency of proverbs was co-operation. In all, there were 12 proverbs $(27.4 \%)$ on co-operation out of the 44 proverbs used in the optional speeches. Patience followed with six (6) proverbs (13.6\%) and hard 
Owu-Ewie, C./Legon Journal of the Humanities Vol. 30.1 (2019)

work with four (4) (9.1\%) proverbs. Respect for in-laws, against polygamy, faithfulness, and sexual denial had three (3) (6.8\%) proverbs each. In addition, there were three themes (excessive friendship, respect for each other, and emulating good behavior) with two (2) (4.5\%) proverbs each. The least expressed themes in the optional speeches as means of counselling the couple were providing security, heeding advice, violence and child bearing. These themes had one (1) (2.3\%) each. The frequency of the proverbs and the themes they portray are represented graphically on the table and bar chart below:

Table 1: Frequency of Akan proverbs and the themes they portray in marriage contraction

\begin{tabular}{|l|c|c|}
\hline THEME & NO. OF PROVERBS & PERCENTAGE \\
\hline Cooperation & 12 & 27.4 \\
\hline Respect for each other & 2 & 4.5 \\
\hline Patience & 6 & 13.6 \\
\hline Hard work & 4 & 9.1 \\
\hline Excessive friendship & 2 & 4.5 \\
\hline Respect for in-laws & 3 & 6.8 \\
\hline Against polygamy & 3 & 6.8 \\
\hline Faithfulness/truthfulness & 3 & 6.8 \\
\hline Providing security & 1 & 2.3 \\
\hline Heeding advice & 1 & 2.3 \\
\hline Against violence & 1 & 2.3 \\
\hline Sexual denial & 3 & 6.8 \\
\hline Emulating good behaviour & 2 & 4.5 \\
\hline Child bearing & 1 & 2.3 \\
\hline Total & $\mathbf{4 4}$ & $\mathbf{1 0 0}$ \\
\hline
\end{tabular}


Figure 1: Bar chart of frequency of Akan proverbs and the themes they portray in marriage contraction

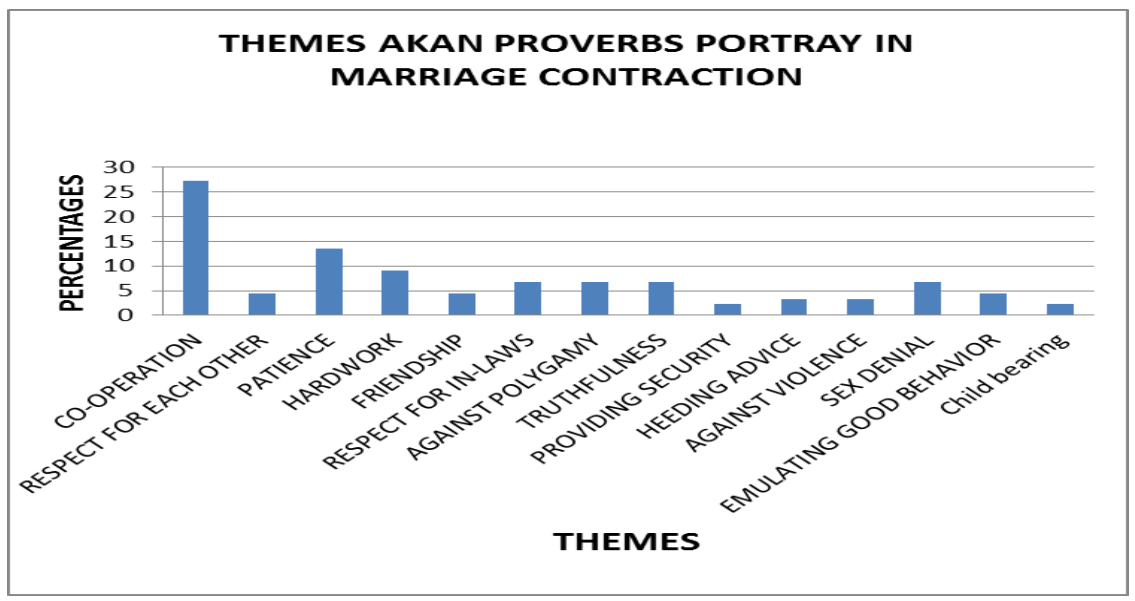

It is clear from the data that none of the optional speakers concentrated on one theme in their speeches. Almost all speakers touched on two or more themes. For example, speaker 2 in episode 3 lay emphasis on about five themes (child bearing, criticism of polygamy, relationship with in-laws, faithfulness and co-operation), while a speaker of episode 1 concentrated on two themes (truthfulness/faithfulness and co-operation). The data indicates that the Akans place emphasis on co-operation, patience, hard work, and sex as important things that ensure a successful marriage. Cooperation was very much emphasized in the optional speeches because it has serious repercussion on any successful marriage. The key to a strong longterm marriage that people aim for is co-operation. Co-operation underpins any successful marriage because all other themes expressed in the optional speeches hinge on it. The speakers essentially stressed on co-operation because the I-want-my-needs-met attitude in marriage without considering the other breaks down the spirit of cooperation in marriage. Proverbs on cooperation should, therefore be highlighted in marriage counselling. Patience was also stressed in advising the couples because co-operation and respect for the other can be achieved when there is patience between the couple. These two elements are crucial to any successful marriage, hence the need for their emphasis in counselling the couples during the optional speeches.

Research Question 3: What are the implications of the study to 
Owu-Ewie, C./Legon Journal of the Humanities Vol. 30.1 (2019)

the professional counsellor's use of Akan proverbs in their day-to-day marriage counselling of their clients?

Proverbs reveal profound thoughts of a people and they are deeply rooted in their souls. They constitute the true index of what a people hold dear. Proverbs encapsulate the form of interpretation of the principles of life and mode of conduct upheld by a people (Kanu, 2015 citing Anozie, 1999). They deal with practical and realistic ideas and real life situations (Isidienu, 2016). Proverbs touch on important issues that are dear to the individual. The accumulated knowledge, wisdom, cultural beliefs and experiences of the Akans are embedded in their proverbs. Proverbs therefore have values and are veritable sources of wisdom that are crucial to counselling people entering into marriage. This ensures that they have a clear understanding of the complexities of marriage. Akan proverbs portray what the Akan cherishes as their worldview and an embodiment of their soul. The implications of this study to contemporary marriage counselling therefore cannot be underestimated. The following are some implications:

- That the professional contemporary marriage counsellor should employ traditional proverbs in their marriage counseling sessions because proverbs portray what the Akan cherishes as their worldview and an embodiment of their soul. It is a built-in or an innate mechanism of the Akan, which needs activation for it to work and help shape their marriage lives.

- That the professional counsellor should know what the Akan society cherishes in marriage and should therefore stress on in their counseling sessions using proverbs. Such proverbs will let the would-be couple think critically on important things that ensure successful marriage and practise them.

- That the contemporary counselor should be acquainted with the culture in general and proverbs in particular of the Akans so that they can use them effectively in their marriage counselling sessions.

- That they should know proverbs, their meanings and implications to help them use such proverbs effectively in their marriage counseling sessions to touch on the inner soul of their counsellees. 


\section{Conclusion}

This paper sought to examine how proverbs can be used as counselling tool in marriage in contemporary times. The study used forty-four proverbs from ten optional speeches in three marriage episodes as the corpus. The themes that were commonly exploited by the speakers through their use of proverbs to advise the couples were cooperation, patience, hard work, respect for in-laws, polygamy, faithfulness and sex. Other themes expressed include excessive friendship, emulating good behaviour, respect for each other, child bearing, providing security, and heeding advice. The most frequently expressed themes were cooperation and patience. The study noted that contemporary marriage counsellors should tap into proverbs in the counselling of their clients because proverbs are at the soul of the Akan and tapping into them makes the couple think critically of what is presented to them and apply them in their marriage life and beyond. 


\section{References}

Aboh, R. (2013). Proverbs and euphemisms as discourse strategies in Joe Ushie's Poetry. African Studies, 72(1), 107-120.

Abrahams, R. (1968). A rhetoric of everyday life: Traditional conversational genres. Southern Folklore Quarterly, 32, 44-59.

Aden, M. B. (2010). Proverbs as artistic discourse strategy in conflict resolution among Kenya Somali. Doctoral thesis, Kenyatta University. Ademowo, A. J. \& Balogun, J. (2014). Proverbs and conflict management in Africa: A study of selected Yoruba proverbs and proverbial expressions. International Journal of Literature, Language and Linguistics, 1(1), 39-44,

Adu Gyamfi, A. A. (1999). Akan mmebusem mu bi. Kumasi: University Press.

Agbemabiese, P. (2016). Gender implications in Ewe proverbs: A close study. Academia.edu. Retrieved from edu.academia/gender_ implications_in_Ewe_proverbs

Agyekum, K. (2012). Akan proverbs and aphorisms about marriage. Research Review, NS 27(2), 1-24

Agyemang, B. C., Asumeng, A. M., \& Amponsah, B. (2015). The relevance of Ghanaian Akan proverbs to explanations of contemporary human resource principles and corporate values. Journal of Business Research, 9, 16-27

Akporobaro, F. B. O. (2008). Introduction to poetry. Lagos: Princeton Publishing.

Aku-Sika, C. M. (2016). Power relations as expressed in selected Ewe proverbs. MPil Thesis: University of Ghana, Legon, Accra.

Alimi, S. A. (2012). A Study of the use of proverbs as a literary device in Achebe's Things Fall Apart and Arrow of God. International Journal of Academic Research in Business and Social Sciences, 2(3), 121-127 Appiah, P., et. al. (2007). Bu me be: Akan proverbs. Accra: Centre for Intellectual Renewal.

Arewa, E. O. \& Dundes, A. (1964). Proverbs and the ethnography of speaking Folklore1 American Anthropologist 66(6), 70 -85

Baragas, D. E. (2010). The functions of proverbs in discourse: The case of a Mexican transactional social network. New York: De Gruyter Mouton. 
Barley, N. (1970). A structural approach to the proverb and maxim with general reference to the Anglo-Saxon corpus. Proverbium, 20, 737750.

Bierce, A. (1911). The devil's dictionary. CA: Albert and Charles Boni Publishing Company

Basgoz, I. (1993). Proverb image, proverb message, and social change. Journal of Folklore Research, 3O(2/3), 127-142.

Clark, B. (2013). Relevance theory. Cambridge: Cambridge University Press.

Chapman, G. D. (2015). The laws of in-laws. Thriving Family Magazine.

Christaller, J. G. A. (1879). Tshi proverbs. Basel: Basel Mission.

Dashnaw, D. (2018). 13 Best ways to show respect in marriage. Retrieved from https://couplestherapyinc.com/13-ways-to-show-respect-inmarriage on $25 / 5 / 19$

Devi, D. (2015). A Study of the usage of proverbs as a literary device in Salman Rushdie's selected novels. International Journal of English. Literature and Culture, 3(10), 266-268,

Dogbovi, E. K. (2011). African proverbs and gender construction: Perspectives on women. Ghana Business News.

Duenwald, M. (September 10, 2002). Some friends, indeed, do more harm than good. New York Times.

Howarth, M. (Jan. 27, 2017). The key to happy marriage. Daily Mail. Retrieved from http://www.dailymail.co.uk/news/article-2546511/ Keep-wife-happy-spend-time-work-Husbands-longer-hours-officestudy-says.html on 02/4/2017

Isidienu, I. C. (2016). Philosophy of Igbo proverbs: The logic, ethics and esthetics in Igbo culture. Journal of Religion and Human Relations, $8(1), 69-83$.

Kanu, I. A. (2015). A hermeneutic approach to African traditional religion, theology and philosophy. Jos: Fab Anieh.

Kquofi, S., Amate, P., \& Tabi-Agyei, E. (2013). Symbolic representation and socio-cultural significance selected Akan proverbs In Ghana. Research on Humanities and Social Sciences, 3(1), 86.

Meurer, D. (2000). Daze of our wives. NY: Bethany House Publishers. Norrick, N. (1985). How proverbs mean: Semantic studies in English proverbs. Berlin: Mouton.

Obiechina, E. (1975). Culture, tradition and society in the West African Novel. Cambridge: Cambridge University Press. 
Owu-Ewie, C./Legon Journal of the Humanities Vol. 30.1 (2019)

Odebunmi, A. (2008). A pragmatic reading of Yerima's proverbs in 'Yemoja Attahiru' and 'Dry Leaves on Ukan Trees'. Intercultural Pragmatics, 3(2), 153-170.

Opoku, A. K. (1997). Hearing and keeping: Akan proverbs. Accra: Asempa Publishers

Quan-Baffour, K. P. (2011). The wisdom of our fathers: Akan Proverbs and their contemporary educational value. Southern African Journal for Folklore Studies, 21(1), 30-38

Ramirez, C. H. (2015). A pragmatic approach to proverbs use and interpretation. MA Thesis submitted to Universidad de Cadiz.

Rasul, S. (2015). Gender and power relationships in the language of proverbs: Image of a woman. FWU Journal of Social Sciences, 9(2). 53-62

Shariati, M. \& Tayebi, S. M. (2012). A comparative study of proverbs' characteristics of Mesopotamian languages and a local dialect of Persian. International Journal of English Linguistics, 2(2). Retrieved from www.ccsnet.org/ijel on 12/4/18.

Searle, J.R. (1975a). Indirect speech acts. In P. Cole and J. I. Morgan (eds). Syntax and Semantics 3: Speech Acts. pp. 59-82. New York: Academy Press.

Simons, H, A. (1946). The proverbs of administration. Public Administration Review, 6(1), 53-67.

Sperber, D. \& Wilson, D. (1986a). Relevance: Communication and cognition.

Oxford: Blackwell, and Cambridge, MA: Harvard University Press.

Sperber, D. \& Wilson, D. (1995). Postface to the second edition of Relevance: Communication and cognition. Oxford: Blackwell.

The Telegraph (March 31, 2018). The key to a happy marriage. Retrieved from

https://www.telegraph.co.uk/men/relationships/10598608/Key-to-ahappy-marriage-is-a-hard-working-husband.html

van Heerden, W. (2013). The proverb is the drum of God': On the use of African proverbs in the interaction between African culture and the Christian faith. Scriptura 81, pp. 462-475

Villers, D. (2016): Proverbiogenesis: The phases of proverbial birth. In proceedings of 9 th Interdisciplinary Colloquium on Proverbs. Tavira: International Association of Paremiology, 369-380.

Wierzbicka, A. (1988). The semantics of grammar. Amsterdam: John Benjamins 
Owu-Ewie, C./Proverbs in marriage: Counselling role and implications

Wilson, D. \& Sperber, D. (1986). Pragmatics and modularity. Chicago Linguistics Society, 22, Part 2. 67-84.

Yankah, K. (1989). The proverb in the context of Akan rhetoric. New York: Peter Lang.

Yankah, K. (2012). The proverb in the context of Akan rhetoric. New York: Diasporic African Press.

Yusuf, Y. K. (1998). Gender bias and images of women in English and Yoruba Proverbs. In M. E. M. Kolawole (ed.). Gender Perception and Development in Africa. Lagos: Arrabon Academic Publishers. 


\section{Appendix \\ Marriage Contraction Episodes \\ Episode 1 \\ Ethnographic Background}

Venue: Aboso in the Shama District of the Western Region of Ghana Date: 25/4/16

Participants: Bride's Family (Eshun Family) and Groom's Family (Ako Family)

Context: (The two families have met at Opanyin Eshun's house to perform the marriage rites for Akua Menanowa and John Ako. The marriage ceremony is about to end and participants have been given the chance to advise the couple)

Optional Speaker1: (Opanyin Ansa, elder brother of the bride's father)

.... эу $\varepsilon$ me enyigye $d \varepsilon$ nd $\varepsilon$ woabctsew wo roks. Mpanyin se, obaa kっ awar a,

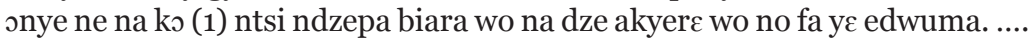

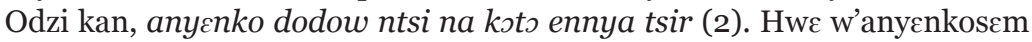

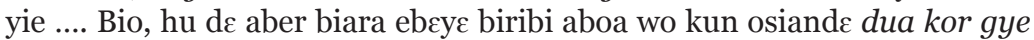
ehum a, obu (3). Odzi ewiei, akwadwer no nua nye menya medzi (4) na hu $\mathrm{d} \varepsilon$ anoma enntu a, obua da (5) ....

\section{English Translation}

(... I am happy that today somebody has come to marry you. The elders say, if a girl (woman) goes to marriage, she goes with her mother so any good thing your mother has taught you practice it. ... First, excessive friendship deprived the crab of a head. Be careful with your friends. ... Again, make sure you will do something to assist your husband every time because if one tree stands in the way of the storm, it breaks. Lastly, the brother of laziness is if I get, I will eat and note that if a bird does not fly, it goes hungry. .....)

\section{Optional Speaker 2 (Bride's uncle)}

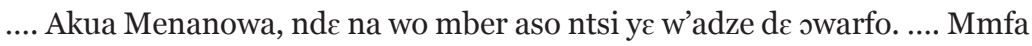
wo kun ekyir nnyc biribiara. Mpanyin se, wonam beenu sua efir a, wonam beenu sera (6). Bio ma abotar ndzi wo kan. Mmper wo ho wo abrabo mu osiande obra wots bo bo (7). Aber biara tsie afotu .... Seanntse nye swam etsiks pow (8). .... Aber biara nnye wo kun ndwen osiande tsir kor mmpam (9) na tsir kor so nnk egyina (10) ......

English Translation

(... Akua Menanowa, today is your time for marriage so do things like a married woman. ....Do not do anything behind your husband. The elders say, when two people set a trap the two watch it together. Again, 
let patience be your guiding principle. Do not rush in life because life is executed with patience. Pay heed to your husband's advice every time ... the hornblower bird has a protruding back head because it did not listen to advice. Think together with your husband all the time because one head does not confer and one head does not deliberate on a case...)

\section{Optional speaker 3 (Opanyin Kofi Ascmpa, groom's uncle)}

Awar nye banyin na basia enyimnyam. Aber biara bo wo yer ho ban. Mpanyin se, basia onnyi kun na yebor no yi akyea (11). ... Hwe yie na ammfa wo nsa annka wo yer. Hu de edze kokrobetsir ko eyi a, wodze asotor gya wo kwan (12). Hwe yie na annye asosombaa osiand awar dodow ma kom dze banyin (13) ....

\section{English translation}

(... Marriage is the dignity of every man and woman. Protect your wife all the time. The elders say, we beat a woman and bluff when she has no husband. ... Be careful you do not raise your hand against your wife. Know that when you attend a funeral with your thumb raised, you are seen off with a slap. Be careful you do not marry more women because a polygamous man goes hungry ...)

\section{Optional Speaker 4 (groom's senior father)}

.... Awarso. Awar mu wo nkukuhwease pii naaso hom nhu de korye ma nkonyimdzi (14) ntsi daa hom nye kor. Hom nnya abotar wo biribiara mu osiand $\varepsilon$ abotar ma nkonyimdzi (15) ..... Ekyir koraa no, hom nnhu de beebiara do ws no, ebufuw nnyi ho (16) ....

\section{English translation}

(Happy marriage! There are so many ups and downs in marriage but you should know that togetherness results in victory so do things together every time. You should have patience because patience moves mountains. .... Finally, you should note that where there is love, there is no anger....) 


\section{Episode 2}

\section{Ethnographic Background}

Venue: Kumasi in the Shama District of the Western Region of Ghana Date: $10 / 4 / 16$

Participants: Bride's Family (Nsia Family) and Groom's Family (Boakye Family)

Context: (The two families have met at Opanyin Ansa's house to perform the marriage rites between Abena Nsia and Yaw Mensa. The marriage ceremony is about to end and participants have been given the chance to advise the couple)

Optional Speech 1 (the bride's father - Opanyin. Kwan Ansa)

.... Agoo, enuanom nd $\varepsilon$ y $\varepsilon$ enyigye da. ... Awar mu wo ntokwa ntsi ntokwa ba a hom nsiesie no dzinn. Bio hom nye kor osiande nkura ye kor no wodzi mbsrkutu (17) demara so huw m'enyi do ma me ntsi na atwe nam beenu beenu (18). Biribiara mu no, hom nsusu ho. Mpanyin se, nyansa nnyi baakofo tsir mu. (19) demara nyimpa kor nsa nnso Nyame enyim kata (20) ......

\section{English Translation}

(Agoo! Brothers and sisters, today is a happy day. .... There are misunderstandings in marriage so when there are misunderstandings solve it peacefully. Again, be united because when a group of mice unite they eat a pot full of dough. In the same way, antelopes walk in pairs because of the idea of removing the peck from one's eye. In all things, dialogue together. The elders say, wisdom does not reside in one person's head. In the same way, one person's hand cannot cover the face of God)

Optional speaker 2 (Bride's grandfather)

Me nananom, mep $\varepsilon$ d $\varepsilon$ mutu hom fo fa edwumadzen na setie ho. Sc hom bedzi yie wo hom awar mu a, ogyina edwumadzen do. Mpanyin se, etse fakor a, etse w'adze do (21). ..... Afei, me ba bre wo ho ase ma wo kun na enya awar mu agyapadze. Abowa kskssekyi dze ne kwasea gye ne nyinkycr

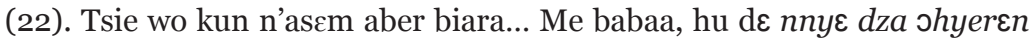
nyina nye sika (23) ntsi ma w'enyi nka wo kun ho. .....

English translation

(My brothers and sisters, I want to advice you about hard work and obedience. If you will succeed in your marriage, it hinges on hard work. Our elders say, if you sit at one point, you sit on your wealth. .... Now, my daughter, be humble before your husband and get all the good things in marriage. The vulture uses its stupidity to have long life. Listen to your husband all the time. .... My daughter, not all that glitters is 
gold so just stay with your husband.)

Optional Speaker 3 (Opanyin Kwaw, an observer)

... Awarfo mema hom tsir nkwa. Egya ndom hom awar mu mba. Hom nhwe hom anyenkosem yie. ... Afei m'awsfase wo so bre woho ase na aber biara tsie dza wo kun beka. Mpanyin se, akoksber nyim adzekyee naaso shwe akoksnyin ano (24). Bio, hom ndzi nsewnom nyi osiand awar wowar no ekyir (25) na awarso na awargu gyina nsewnom do (26) ntsi hom nhwe hon yie......

\section{English translation}

(.... Couple, I give you happy marriage/congratulations. May the Father provide you with children in your marriage. Be careful with excessive friendship.... Now, my niece, you must be humble and listen to what your husband will say. Our elders say, the fowl knows it is daybreak but it looks at the cock. Again, respect your in-laws because marriage thrives on those behind the marriage (in-laws) and the success or collapse of a marriage depends on in-laws so take good care of them .....)

\section{Optional Speaker 4 (Op. Kofi Abora from groom's family)}

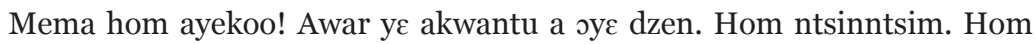
mboaboa hom ho. Hom nhu de nsa nyimfa guar benkum na benkum so guar nyimfa (27). ... M'awsfaase, mpanyin se, sc nyin annwen na ber wen a, wəda mu (28). Me babaa, do wo kun na tsie n'asem, ... obaa od॰ no kun əse morohwe wo ara (29). .... Hom ndzi nokwar mma hom osiande nokwardzi ma nkonyim (30). Bio, nokwardzi (so) ye awar mu kandzea (31). Odzi ewiei, mmfa wo ho nnkam wo kun; mpanyin se, akoks yє ne ba səesəe a, akorsma kyer no (32). Hom ntsena asomdwee mu....

\section{English translation}

(I bid you greetings! Marriage is a difficult journey. Be careful. You should help each other. You should recognize that the right hand washes the left and the left washes the right. My nephew, the elders say, if the man does not weave and the woman weaves, we sleep in it. My daughter, love your husband and listen to him ... A woman who loves the husband, say I am looking at you. .... Be truthful to each other because truthfulness brings success. Again, truthfulness is the light in marriage. Finally, do not deprive your husband of sex; the elders say that if the fowl drives its chicks away, the hawk snatches them. Stay together in peace ...) 
Owu-Ewie, C./Legon Journal of the Humanities Vol. 30.1 (2019)

\section{Episode 3}

\section{Ethnographic Background}

Venue: Aboso in the Shama District of the Western Region of Ghana

Date: $17 / 5 / 16$

Time: 10:00 am

Participants: Bride’s Family (Amissa Family) and Groom's Family (Bekoe Family)

Context: (The two families have met at Opanyin Amissa's family house to perform the marriage rites between Akua Wobirba and Kwame Beesi. The marriage ceremony is about to end and participants have been given the chance to advise the couple)

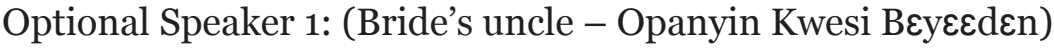
... Awarfo, mema hom tsir nkwa. Twerammpon Kwame nhyira hom. M'afotu ara nye de hom nhu de awar no kwan war ara yie ntsi hom nnya abotar osiande abotar tutu nkokwaa (33) na isie abotar kum ntsetse\& a, ihu no nson (34). Hom nhu de awar mu enyimnyan nye mba (35) ntsi mma hom nnkyer na hom ama me nana. Iyi ekyir no, hom nhwe hom ho yie

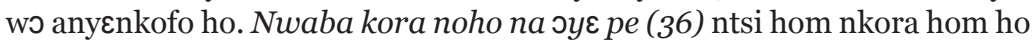

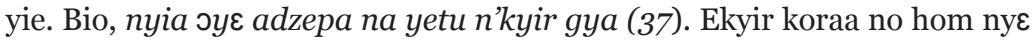
edwumadzen nhwe hom mba na awofo. Mpanyin se, edwumadzen nnku nyimpa (38).

English translation:

(... Couple, happy marriage! May the Almighty God bless you. My advice is that know that marriage is a very long journey so you should have patience because patience move mountains. If you dissect the ant with a lot of patience, you see the intestines. Note that reputation in marriage is children so do not hesitate in giving ma a grandchild. Besides, be careful about friendship. The snail that takes care of itself becomes a giant one so take very good care of yourself. Again, we emulate someone who does good things. Finally, work hard to take care of your children and your parents. The elders say, hard work does not kill anyone.)

Optional Speaker 2: (Chief's spokesperson who was at the ceremony as a witness - okyeame Kwaw Bentum)

Agoo! Enuanom na adofo medze nkyia fi Nana na ne mpanyimfo ho bre hom. Nana ma hom akye; ose wogye no ahenewa. Awarfo, afotu a Nana se me mfa mma hom ara nye odo, korye na abotar. Maame Wobirba, 
mpanyimfo se, atopa na oma awar so (39) ntsi mmfa woho nkam wo kun ara da. Demara so na me Nana Beesi wo so hu no de se edwanse fakor a, otwa ehur (40); ma w'enyi nka wo yer ho osiande awar dodow so ma banyin ano ye nta(41). Afei hom nsan nhu de awar wowar no ekyir (42)

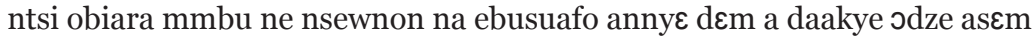
beba. Bio, hom nhu de nokwardzi nye awar no kutuwdobo (43) ntsi hom

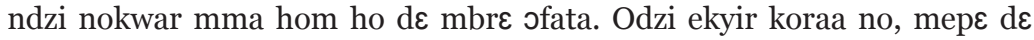
hom hu d $\varepsilon$ nkabom hia wo awar mu. Hom nka hom ho mbo mu de pradze. Mpanyin se, pradze kunkumfi no bu ye buna (44). Mpanyimfo a hom ehyia wo ha nyina meda hom ase. Awarfo mema hom tsir nkwa.

\section{English translation}

(Agoo! Brothers and sisters and all loved ones, I send you greetings from the chief and his elders to you all. He says his greeting response is Ahenewa. Couple, the advice to you from Nana is love, togetherness and patience ... Maame Wobiriba, the elders say, sex makes marriage thrive so never deprive your husband of sex. In the same vein, Nana Beesi you must also know that if you urinate at one spot, it gives more foam. Let your eye be on your wife because polygamy makes a man have double tongue. After this, you must also note that a marriage thrives better based on the people behind the marriage so everybody should respect his/her in-laws else it will bring problem one day. Again, note that truthfulness is the bedrock of marriage so be truthful to each other. Finally, I want you to know that unity and cooperation is key in marriage. You must come together like a broom. The elders say, if you take a broom stick, it is easy to break but it is not easy to break them, if they are together. All elders gathered here, I thank you. Couple, I say congratulations!) 